\title{
Financing of Micro, medium and small scale enterprises in India Key Challenges
}

\author{
Biswajit Bose \\ Assistant Professor of Commerce, Gyan Jyoti College, Affiliated to University of North Bengal, India
}

\begin{abstract}
Micro, small and medium sector enterprises have a vital role in in the economic growth of a developing nation like India. These enterprises play a catalyst role in the development of industrial and commercial activities. In the overall value chain of different industries these firms are placed in critical positions. It is, therefore, imperative to focus on the issues which impact the creation, survival and growth of the firms of the sector. One of such prime issues is the need of credits by these firms.

This paper delineates the need of greater attention on the financing requirement of MSME sector. The firms need credit assistance at different stages of their life cycle. The unique characteristics of this type of firms imply that their credit needs deserve focused attention. Therefore, the banks and other financial institutions have the responsibility to offer such credit products and financing schemes which address the requirements of MSME sector. In meeting this financing requirement, problems may arise with respect to asset quality of the financial institutions. In order to promote the sector, there is a need to create an enabling environment which can ensure credit flow and at the same time address concerns regarding management of credit made to the sector.
\end{abstract}

Keywords - MSME, Credit Flow, Asset Quality.

\section{Role OF CAPITAL IN MSME SECTOR:}

The challenges faced by Micro, Small and Medium Enterprises (MSME) sector arise from multiple factors. These enterprises being small in sizes have limited ability to withstand any economic shock. They are generally running with inadequate amount of capital. A large number of enterprises depend completely on the owner's capital and revenue from the businesses, without borrowing funds from financial institutions. It naturally inhibits their potential to grow their businesses. Many of the concerns of this sector like low technology level, lack of product variants, inability to increase manpower etc. cannot be addressed without adequate and timely availability of credit. It is only when these enterprises are adequately funded, would they be able to invest in creating distribution network, brand building, technical know-how, R\&D etc. Also, these enterprises often being the suppliers of larger enterprises suffer from the problem of the realisation of payments for their products or services. This phenomenon puts pressure on their working capital which impacts severely their operations. Therefore, in the one hand they have limited capital to invest in fixed assets to expand their operations; on the other hand, due to lack of adequate working capital they find it difficult to continue their existing operations. The concerns are not confined to issue of credit availability; it's also about cost of credit. If the cost of credit cannot be made attractive for the borrowers of this sector, loan disbursal cannot be improved.

The MSME sector, therefore, urgently needs more capital at a reasonable cost. The availability of funding can help it to address some of its key concerns. It needs more seed capital to start new ventures. Long term capital is needed to help the enterprises to invest in infrastructure in terms of land, plant \& machinery, technology sourcing etc. and to augment its operations. Working capital is required to finance mismatch between payables and receivables and to ensure uninterrupted running of operations of the business. In the face of global and national-level competition, flow of funds is critical for the survival and growth of MSMEs.

Not only these firms need debt financing, the growth cannot take place without equity financing. There is a possibility of growing firms taking only bank finance, getting over-leveraged. At that point further bank financing is hard to get. Therefore, the MSMEs can grow by having the access to both debt financing and equity financing options.

\section{SOURCES OF FINANCING FOR MSMES:}

The MSMEs in India largely depend on self-finance. As per the fourth census of MSME sector 87.23\% of all enterprises were found in the category of taking "self-finance/No finance". This high percentage of units depending on "self-finance/No finance" can be a result of high proportions of units falling in "Micro enterprises" category. Micro enterprises comprise $94.94 \%$ of all the MSME units in India, whereas the share of small enterprises is $4.89 \%$ and that of medium enterprises is only $0.17 \%$. 


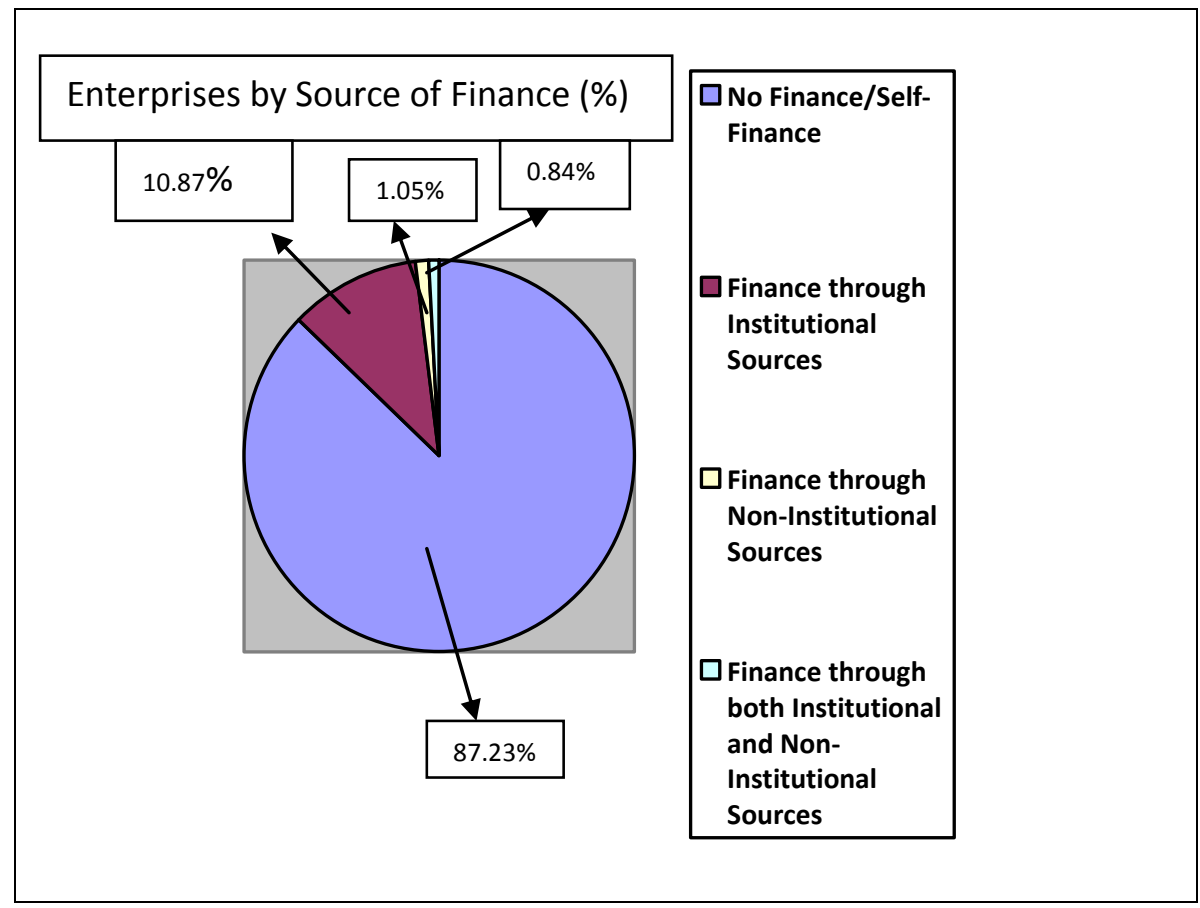

Source: Final Report (Edition: April 2011) 4th All India Census of MSME, 2006-07 Registered Sector

Enterprises by Type

\begin{tabular}{|l|l|l|}
\hline Type & No.(Lakh) & $\begin{array}{l}\text { Proportion in total working } \\
\text { enterprises (\%) }\end{array}$ \\
\hline Micro Enterprises & 14.85 & 94.94 \\
\hline Small Enterprises & 0.76 & 4.89 \\
\hline Medium Enterprises & 0.03 & 0.17 \\
\hline
\end{tabular}

Source: Final Report (Edition: April 2011) 4th All India Census of MSME, 2006-07: Registered Sector

The MSMEs which fall in unorganised sector continue to take credit heavily from the informal financial sector. The active participation of informal financial entities in lending is a result of several advantages that these firms consider as significant. The informal financial sector has access to information through the social and personal networks. It helps to develop a relationship of trust and confidence which is important in the absence of adequate amount of collateral.

MSMEs perceive that the least usage of paper work and absence of administrative sluggishness and rigidities make the availability of loans from informal sources quicker as compared to formal banking system. The timeliness, convenience and simpler process of informal financial entities attract the borrowers of MSMEs.

The banking sector has also been an important source of finance for MSMEs, especially, for those which are in organised sector. The following table indicates the outstanding bank credit to micro and small enterprises.

\section{Outstanding Bank Credit to micro and small enterprises (Rs. Crores)}

\begin{tabular}{|l|l|l|l|l|}
\hline $\begin{array}{l}\text { As on last reporting } \\
\text { Friday of March }\end{array}$ & $\begin{array}{l}\text { Public Sector } \\
\text { Banks }\end{array}$ & $\begin{array}{l}\text { Private Sector } \\
\text { Banks }\end{array}$ & Foreign Banks & $\begin{array}{l}\text { All Scheduled } \\
\text { Commercial Banks }\end{array}$ \\
\hline 2008 & 151137 & 46912 & 15489 & 213538 \\
\hline 2009 & 191408 & 46656 & 18063 & 256127 \\
\hline 2010 & 278398 & 64534 & 21069 & 364011 \\
\hline 2011 Provisional & 376625 & 87857 & 21461 & 485943 \\
\hline
\end{tabular}

Source: MSME Annual Report 2011-12.

The scheduled commercial banks have increased their lending to micro and small enterprises in the recent years. The outstanding credit by all scheduled commercial banks to these enterprises increased by $19.9 \%$ in 2009 , $42.1 \%$ in 2010 and $33.5 \%$ in 2011. In this context it should be noted that bank's lending to the Micro and Small Enterprises is considered as priority sector advances, but lending to medium enterprises is not eligible to be included for the purpose of computation of priority sector lending.

Banks are introducing loan products catering MSMEs exclusively. India's commercial banks are now launching loan products which are covered by Credit Guarantee Trust Fund for Micro and Small Enterprises (CGTMSE). This Scheme is an initiative of Government of India to strengthen credit delivery system and 
facilitate flow of credit to micro and small enterprises. Under this scheme banks are encouraged to give more importance to project viability and secure the credit facility purely on the primary security of assets financed. Despite the growth in credit to MSME sector, it has to be acknowledged that larger number of units are not availing loans from financial institutions including banks. Banks have in recent times been trying to address the perception of borrowers with respect to issues such as collateral, procedural delays, information asymmetry etc. There is a need to utilise the alternative sources of capital with a greater vigour. This is especially required for the knowledge based service industries. As many of these enterprises, despite being small, are involved in using advanced technology and innovative business models, the availability of risk capital play a role of catalyst in their growth. In the context of MSME, risk capital refers to pure equity or quasi equity/mezzanine financial products for meeting the seed, development and growth capital requirements.

Business Angel Networks (BAN) are not very active in India in providing seed capital to MSMEs. Unlike many developed countries like UK and USA, intermediaries are not present to link the MSMEs with the informal investors. MSMEs in India are starved of equity capital. The small ticket size, high transaction cost, valuation and exit issues, lack of willingness in promoters in diluting ownership/control are making the sector unattractive for external equity financing by Private Equity and Venture Capital funds. Due to lack of Owners' capital i.e. margin, MSMEs also find it difficult to get assistance in the form of working capital.

In order to address the lack of financing of small and medium enterprises through equity capital, Prime Minister's Task Force in 2010 recommended setting up of dedicated stock exchange/platform for SME. In response to this recommendation the Securities and Exchange Board of India (SEBI) laid down the regulation for the governance of SME Platform. In March 2012, Bombay Stock Exchange (BSE) launched its SME Platform. The listing of firms can help in several ways such as improving the future financing opportunities, getting more favourable lending terms from financial institutions, increasing visibility and credibility which in turn can attract diverse set of investors.

The MSMEs face the problem of receivables management without adequate financing opportunities through factoring services. The delayed payment by the purchasers from larger enterprises has always been an issue of great concern for the MSMEs. Financial Institutions in India have to be more proactive in providing finance against the receivables factored. Globally, factoring is a preferred route of accessing working capital for SMEs. The enactment of Factoring Regulation Act in 2011 in India is expected to give boost to factoring services. Factoring offers benefits like open account facility which means credit limit increases as sales grow, provided the firm has a satisfactory record of payments.

\section{Concerns involved in providing finance to MSMEs:}

The growth in providing finance to MSMEs cannot be achieved without addressing the concerns of formal financial institutions like banks in lending to this sector. MSMEs are considered as high risk borrowers due to factors such as insufficient assets and low capitalisation. The firms being highly vulnerable to economic and marketing fluctuations have high mortality rates. According to Reserve Bank of India (RBI) data, the number of sick units in MSME sector has increased by 16\% to 90,141 units in March 2011 from 77,723 units in March 2010. As per current definition, a unit is considered sick when any of the borrower account of the unit remains substandard for 6 months or there is erosion in the net worth due to accumulated cash losses to the extent of 50\% of its net worth during the previous accounting year and the unit has been in commercial production for at least two years.

For the financial year 2011-12, the share of Micro and Small Enterprises in banking system credit was 9.8\% whereas the share of these firms in banking system Non Performing Assets (NPA) was as high as $17.9 \%$. Large number of MSMEs turning sick units and the rising trend of NPA pose a significant risk for the banks. The information asymmetry that exists in lending to MSMEs act as an obstacle in ensuring credit flow to the sector. The credit information about small enterprises is not easily available and it is not cost effective for the banks to collect information on large number of small enterprises.

This often results into lending rates being loaded with the cost of information asymmetry. Information asymmetry makes it difficult for the lenders to distinguish between bankable projects and doubtful projects.

As per the 4th census of MSME sector $90.08 \%$ of the enterprises are of proprietary in nature. Such a large proportion being dependent on the proprietors and without having succession planning in most cases make the sector unattractive for the lenders. The inability of smaller firms to hire appropriate manpower means that they rely on the proprietors too heavily. In the absence of adequate collateral offered by the most MSMEs, financial institutions depend on the technical, managerial and marketing skills of borrowers to service the loan which increases the risk profile of these firms. The other problems that lenders find in dealing with MSMEs are lack of transparency and reliability of data, lack of financial discipline and inability to provide sound financial track record. 


\section{CONCLUSION:}

Despite various policy initiatives of Government and guidelines by RBI, there still exists demandsupply mismatch in the availability of finance for the MSMEs. Lacks of timely and adequate credit have always been constraints for the MSMEs. The share of micro enterprises in the total number of MSMEs in India is disproportionately high. The reach of formal financial institutions has been limited in providing banking services to these firms. The size and financial exclusion have meant that most of these firms rely on the selffinance and retained earnings. The capacity building is therefore extremely vital for these firms to become more competitive, productive and viable. The strengthening of the sector cannot happen if these firms remain starved of financing opportunities. In the one hand, there is a pressing need to improve the basic infrastructure like roads, electricity and water supply etc. On the other hand, adequate availability of finance can help these firms in improving the products, processes and technology. It must be noted that the country is witnessing the emergence of small but innovative firms, especially in the services sector which are modern in their outlook and they need assistance in the form of risk capital. There has to be continuous focus on the development of lending products to suit the varied requirements of these firms considering the diverse set of firms that constitute this sector. The Indian SMEs have played a vital role in making partnership with larger firms and bringing products in the market at a competitive price. As a valued partner of larger enterprises in the supply chain, many of these firms have also undertaken modernisation initiatives to keep pace with the changing time. The contribution of these firms demands that the bottlenecks in getting credit be removed. It is true that a large number of enterprises becoming sick units increases risk perception of the lenders. The NPA of banks resulting from lending to this sector is also very high. The setting up of Credit Information Bureau of India Limited (CIBIL) can strengthen the credit information infrastructure. This can enhance the confidence of the lending institutions in extending the credit to the MSMEs. It is important to increase the level of awareness about MSMEs about the policy measures and institutional measures aimed to facilitate credit flow to the sector. The MSME sector can evolve to be more competitive and contribute more significantly towards India's goal of sustainable and inclusive growth with the greater access to finance.

\section{REFERENCES:}

[1]. Report of Prime Minister's task force on Micro, Small and Medium Enterprises, Govt. of India, January, 2010.

[2]. Vision 2020: Implications for MSMEs (2011), Grant Thornton, FICCI.

[3]. Chakrabarty K.C. (June, 2010). Bank Credit to MSMEs: Present status and way forward, RBI monthly Bulletin.

[4]. Annual Report, (2010-11). Ministry of Micro, Small and Medium Enterprise, Government of India.

[5]. Badulescu Daniel. SMEs Financing: The extent of Need and the Responses of Different Credit Structures.

[6]. Final Report (Edition: April, 2011) 4th All India Census of MSME, 2006-07: Registered Sector.

[7]. Risk Capital and MSMEs in India (A SIDBI Pulication). 